\title{
Antimicrobial and Antioxidant Activity of Saposhnikovia divaricata, Peucedanum japonicum, and Glehnia littoralis
}

M. KIM, K. -S. SEO' AND K. W. YUN², *

Department of Pharmacy, College of Pharmacy, Sunchon National University, Suncheon 57922, ${ }^{1}$ Jangheung Research Institute for Mushroom Industry, Jangheung 59338, ${ }^{2}$ Department of Oriental Medicine Resources, Sunchon National University, Suncheon 57922, Republic of Korea

Kim et al.: Antimicrobial and Antioxidant Activity of Umbelliferae Plants

Saposhnikovia divaricata, Peucedanum japonicum, and Glehnia littoralis of the family Umbelliferae, have long been used as traditional herbal medicine in Asian countries. This study is the first to compare and 
analyse the relationship between antimicrobial activity, antioxidant activity, and total polyphenol content of Saposhnikovia divaricata, Peucedanum japonicum, and Glehnia littoralis. The four fractions of hydromethanol extract of these 3 plants were evaluated using the disc diffusion method to determine the minimum inhibitory concentration against 5 different bacterial strains. The ethyl acetate fraction was the most effective against the bacterial strains investigated. The 1,1-diphenyl-2-picryl-hydrazyl free radical scavenging activity was evaluated to measure antioxidant activity. The antioxidant activity of the ether and ethyl acetate fractions was in the order of Saposhnikovia divaricata $>$ Peucedanum japonicum>Glehnia littoralis. The total polyphenol content of Saposhnikovia divaricata was greater than that of Peucedanum japonicum and Glehnia littoralis. Even though the 3 plants belong to the same family and are used for similar medical purposes, their antimicrobial activity, antioxidant activity, and total polyphenol content was different. This study would help researchers to uncover the critical aspects of the activities possessed by plants.

Key words: Glehnia littoralis, Peucedanum japonicum, Saposhnikovia divaricata, antimicrobial activity, antioxidant activity, minimum inhibitory concentration, DPPH free radical scavenging activity

Saposhnikovia divaricata (also known as Ledebouriella seseloides, SD), Peucedanum japonicum (PJ), and Glehnia littoralis (GL) have long been used in traditional medicine under the name of Bangpung in Korea, which is also known as Fang Feng in traditional Chinese herbal medicine and Bofu in Japan. These plants belong to the Umbelliferae family and are assumed to have similar effects. These are commonly used as ingredients in many polyherbal preparations designed to dispel "wind" and to induce sweat, alleviate rheumatic conditions, and relieve spasms. They have also been used to treat cough and neurological diseases. The active constituents reported from these plants were essential oils, mannitol, bitter glycoside, chromones, coumarins, and polyacetylenes ${ }^{[1]}$.

Investigations of the antimicrobial activity of medicinal plants has been an ongoing activity. Compounds isolated from plants that possessed antimicrobial activity include terpenoids, saponins, phenolics and phenylpropanoids. Many plants used as aromatic herbs and spices have been reported to have antimicrobial activity and antioxidant activity, while phenolic compounds are often used as aromatizants or antioxidants in the food industry $^{[2-6]}$. It is well-known that free radicals induce oxidative stress, which might cause damage to lipids, proteins, and nucleic acids in the body and result in various diseases. The harmful effects of free radicals can be attenuated by antioxidants, and the 1,1-diphenyl2-picryl-hydrazyl (DPPH) free radical scavenging assay is a common method to determine the antioxidant potential of plant extracts ${ }^{[7-9]}$. Antioxidant activity of phenolic compounds widely distributed in plants could be of value to human health. Total phenolic content and antioxidant activities are strongly correlated, and a relationship between phenolic compounds and antimicrobial activity has also been reported ${ }^{[10-13]}$. However, no studies have compared the antimicrobial activity, antioxidant activity and phenolic contents of SD, PJ and GL.

The main components of SD, PJ and GL reported were phenolics including coumarine derivatives (psoralen, bergapten, imperatorin), coumarin isomer, chromone and its derivatives (divaricatol, ledebouriellol, hamaudol) and flavonoids (rutin, ferulate). These phenolic compounds are known to have various biological effects including analgesic and antiinflammatory activity ${ }^{[14,15]}$.

The present study was conducted to assess the differences in the antimicrobial activity, DPPH free radical scavenging activity, and total polyphenol content of the three aforementioned species of the Umbelliferae family. To accomplish this, the disc diffusion method was applied to measure the minimum inhibitory concentration (MIC) of partitioned fractions of the methanol extract against five different bacterial strains, including three Gram-positive and two Gramnegative bacteria. To measure the radical scavenging activity, we used a DPPH assay, while the total polyphenol content was determined using the modified Folin-Denis method ${ }^{[16]}$. L-Ascorbic acid, DPPH, FolinDenis' reagent, tannic acid and sodium carbonate were

This is an open access article distributed under the terms of the Creative Commons Attribution-NonCommercial-ShareAlike 3.0 License, which allows others to remix, tweak, and build upon the work non-commercially, as long as the author is credited and the new creations are licensed under the identical terms 
purchased from Sigma-Aldrich. All solvents and other chemicals were purchased from Dae-Jung and Junsei Chemical.

SD root was purchased from a commercial market, while PJ and GL were collected from Jindo Island in the southern portion of Korea. The materials were authenticated by Prof. K. W. Yun and Voucher specimens were deposited in the Herbarium of Sunchon National University, Korea. The root part of the plants was used for all experiments. The collected samples were air-dried for $14 \mathrm{~d}$, after which they were extracted with hydro-methanol.

The tested microorganisms included three Grampositive bacteria (Bacillus subtilis ATCC 9327, Lysteria monocytogene ATCC 15313 and Staphylococcus aureus ATCC 13301) and two Gram-negative bacteria (Escherichia coli ATCC 15489, and Salmonella typimurium KCCM 11862). The Gram-positive and the Gram-negative bacteria were cultured on nutrient broth agar at $30^{\circ}$ for $18-24 \mathrm{~h}$.

The air-dried roots were pulverized using an electric mill, after which $200 \mathrm{~g}$ of the powdered root was macerated with $1000 \mathrm{ml}$ of methanol/water (80: $20 \mathrm{v} / \mathrm{v}$ ) for $24 \mathrm{~h}$. The percolates were then filtered through Whatman No. 2 filter paper. Next, the crude hydro-methanol extract was subsequently fractionated with $500 \mathrm{ml}$ of hexane, after which the top hexane layer (comprising the hexane fraction) was concentrated. The remaining layer was successively partitioned with $500 \mathrm{ml}$ of diethyl ether, ethyl acetate and water in a separating funnel (forming the ether, ethyl acetate and water fractions). Each fraction was subsequently concentrated in vacuo to $30 \mathrm{ml}$ at $30^{\circ}$ and tested for antimicrobial, antioxidant activity and the total polyphenol content.

Each bacterial strain was grown in a nutrient broth at $30^{\circ}$ for $18-24 \mathrm{~h}$ prior to testing, then subcultured three times for another 18-24 h. The turbidity of bacterial cell suspensions was brought to 0.3 optimal density at $660 \mathrm{~nm}$ by adding sterile broth and was then used for the tests. Next, $10 \mathrm{ml}$ of the bacterial cell suspensions was poured uniformly onto nutrient agar plates and then paper disks $(8.0 \mathrm{~mm}$ in diameter) containing the hexane, ether, ethyl acetate, or water fractions of the extracts were carefully placed on the bacteria-seeded Petri dishes. The diameters of the resulting zones of inhibition were measured in $\mathrm{mm}$ after the cultures were incubated for 24 or $48 \mathrm{~h}$ at $30^{\circ}$. The diameter of inhibition zone was measured ${ }^{[17,18]}$. The MIC was determined as the lowest concentration that caused an inhibition zone.

The DPPH free radical scavenging activity was evaluated using the Blois method (1958) ${ }^{[19]}$, with slight modification. Briefly, $160 \mu 1$ of each fraction sample was mixed with $40 \mu 1$ of $1.5 \times 10^{-4} \mathrm{M}$ DPPH solution (in methanol) solution. The mixtures were gently mixed and allowed to stand at room temperature for $30 \mathrm{~min}$, and the absorbance at $520 \mathrm{~nm}$ were measured using a microplate spectrophotometer reader (Molecular Devices). The antioxidant activity of each fraction was expressed in terms of $\mathrm{IC}_{50}$ values (the concentration required to inhibit DPPH radical formation by $50 \%$ ). L-Ascorbic acid was used as reference.

The total polyphenol content was determined using the Folin-Denis method, with slight modification ${ }^{[16]}$. The fractions were centrifuged at $1200 \mathrm{rpm}$ for $10 \mathrm{~min}$, and the supernatant collected. The clear supernatant of the samples $(0.5 \mathrm{ml})$ were mixed with $8 \mathrm{ml}$ of distilled water, after which $0.5 \mathrm{ml}$ of Folin-Denis' reagent was added. After $3 \mathrm{~min}, 1 \mathrm{ml}$ of sodium carbonate (10\% in distilled water) was added and the solution was allowed to stand for $2 \mathrm{~h}$ at $22^{\circ}$ in darkness. The absorbance was then measured at $700 \mathrm{~nm}$ using an UVVis spectrophotometer (HP-8453, USA). A standard curve prepared from tannic acid (50-300 mg/l) was used for quantification and the total polyphenol content was expressed as mg tannin/g dry weight.

All tests and analyses were carried out in triplicate and each experiment was repeated three or four times. The data shown here represent the mean \pm standard deviation. The statistical significance was determined by analysis of variance (ANOVA) followed by Duncan's multiple range test.

The antimicrobial activity and MIC of fractions of methanol extracts from the three test plants root are shown in Table 1. The ether and ethyl acetate fractions of SD and PJ showed activity, while GL primarily showed activity in the ethyl acetate fraction. Overall, the ethyl acetate fraction showed a strong inhibitory effect against bacterial growth and Gram-negative bacteria were more sensitive than Gram-positive bacteria to the three test plants. The MIC values indicated that E. coli was the most sensitive investigated microorganism $(\mathrm{MIC}=0.1 \mathrm{mg} / \mathrm{ml}$ ) to all three test plants. Additionally, SD and PJ were more effective against both Gram-positive and Gram-negative bacteria, while GL was only effective against Gramnegative bacteria. In the case of PJ, the ethyl acetate 
fraction was effective against all five bacterial strains at a MIC of $0.1 \mathrm{mg} / \mathrm{ml}$ (Table 1).

Antioxidant activity was determined by DPPH assay and expressed as $\mathrm{IC}_{50}(\mu \mathrm{g} / \mathrm{ml})$, which was the amount of sample needed to scavenge $50 \%$ of initial concentration of the free radical. Results of the $\mathrm{IC}_{50}$ values revealed that ether and ethyl acetate fraction of methanol extract from the three plants had higher scavenging activity when compared with the hexane and water fraction (Table 2). Specially, the order of DPPH antioxidant activity of the ethyl acetate fraction was PJ $(5.42 \mu \mathrm{g} / \mathrm{ml})>\mathrm{GL}(16.66 \mu \mathrm{g} / \mathrm{ml})>\mathrm{SD}(30.54 \mu \mathrm{g} / \mathrm{ml}$; Table 2).

Phenolic compounds have been investigated in many medicinal plants. The total phenolic content of the three plants was shown in Table 3. It was observed that the amount of total phenolic content in ether and ethyl acetate fraction was high, and low in hexane and water fraction. It showed that in ethyl acetate fraction of PJ $(57.42 \mathrm{mg} / \mathrm{g})$ presented higher total phenolic followed by GL $(31.66 \mathrm{mg} / \mathrm{g})$ and SD $(26.32 \mathrm{mg} / \mathrm{g})$.
Plant derived bioactive substances especially with antioxidant and antimicrobial activities could be of potential use to pharmaceutical and food industry and to the consumers ${ }^{[4,20,21]}$. SD, PJ and GL have been used in a variety of herbal medicines under the assumption that they all have similar effects. However, the present study demonstrated that there are notable differences among the antimicrobial activities, DPPH free radical scavenging activities and total polyphenol contents of these plants. SD is known to have tumor cell growth inhibitory effects and antioxidant activities. Additionally, chromone extract of SD has antirheumatoid effects that occur via inhibition of nuclear factor-kappaB (NF-kB) and mitogen-activated protein kinases (MAPK) ${ }^{[9,22,23]}$. PJ has antiobesity effects that occur via phenolic compounds such as neochlorogenic acid, chlorogenic acid and rutin, as well as antiplatelet activity induced by khellactone and monoamine oxidase inhibitory effects exerted by coumarine ${ }^{[24-27]}$. GL has antioxidant effects, antiinflammatory effects that occur via coumarin derivative imperatorin, antibacterial

TABLE 1: MIC OF EACH FRACTION OF HYDRO-METHANOL EXTRACTS OF S. DIVARICATA, P. JAPONICUM AND G. LITTORALIS AGAINST GRAM-POSITIVE AND GRAM-NEGATIVE BACTERIA

\begin{tabular}{|c|c|c|c|c|c|}
\hline \multirow{3}{*}{ Species } & \multicolumn{5}{|c|}{ Minimum Inhibitory Concentration (MIC, $\mathrm{mg} / \mathrm{ml}$ ) } \\
\hline & \multicolumn{3}{|c|}{ Gram-positive } & \multicolumn{2}{|c|}{ Gram-negative } \\
\hline & B. subtilis & S. aureus & L. monocytogene & S. typhimurium & E. coli \\
\hline \multicolumn{6}{|l|}{ S. divaricata } \\
\hline Hexane & 1.5 & - & - & - & 0.2 \\
\hline Ether & 0.5 & 0.3 & 2.0 & 0.2 & 0.2 \\
\hline Ethyl acetate & 0.2 & 0.2 & 0.2 & 0.1 & 0.1 \\
\hline Water & 1.0 & - & - & - & - \\
\hline \multicolumn{6}{|l|}{ P. japonicum } \\
\hline Hexane & - & - & - & - & 0.3 \\
\hline Ether & 2.0 & 0.5 & 1.5 & 0.5 & 0.3 \\
\hline Ethyl acetate & 0.1 & 0.1 & 0.1 & 0.1 & 0.1 \\
\hline Water & - & - & - & - & - \\
\hline \multicolumn{6}{|l|}{ G. littoralis } \\
\hline Hexane & - & - & - & - & - \\
\hline Ether & - & - & - & - & 0.5 \\
\hline Ethyl acetate & 2.0 & 1.5 & - & 0.2 & 0.1 \\
\hline Water & - & - & - & - & - \\
\hline
\end{tabular}

TABLE 2: DPPH FREE RADICAL SCAVENGING ACTIVITY OF EACH FRACTION OF HYDRO-METHANOL EXTRACT OF S. DIVARICATA, P. JAPONICUM AND G. LITTORALIS

\begin{tabular}{lccccc}
\hline \multirow{2}{*}{ Species } & \multicolumn{5}{c}{$\mathrm{IC}_{50}(\mu \mathrm{g} / \mathrm{ml})^{\mathrm{a}}$} \\
\cline { 2 - 6 } & Hexane & Ether & Ethyl acetate & Water & Ascorbic acid \\
\hline S. divaricata & $145.53 \pm 12.17$ & $5.30 \pm 0.05$ & $30.54 \pm 1.33^{\mathrm{a}}$ & $186.91 \pm 4.28^{\mathrm{a}}$ & \\
P. japonicum & $246.71 \pm 43.65^{\mathrm{a}}$ & $46.03 \pm 5.85$ & $5.42 \pm 0.05$ & $104.97 \pm 5.90$ & $3.04 \pm 0.05$ \\
G. littoralis & $44.64 \pm 3.22$ & $71.43 \pm 16.00^{\mathrm{a}}$ & $16.66 \pm 0.29$ & - & \\
\hline
\end{tabular}

aMeans \pm standard deviation with the same letters within a column are not significantly different at $\mathrm{p}=0.05$ according to Duncan's multiple range test. '-' not detected 
TABLE 3: TOTAL POLYPHENOL CONTENT OF EACH FRACTION OF HYDRO-METHANOL EXTRACT OF S. DIVARICATA, P. JAPONICUM AND G. LITTORALIS

\begin{tabular}{lcccc}
\hline \multirow{2}{*}{ Species } & \multicolumn{4}{c}{ Total polyphenol content (mg/g dw) } \\
\cline { 2 - 5 } & Hexane & Ether & Ethyl acetate & Water \\
\hline S. divaricata & $12.53 \pm 2.17^{\mathrm{a}}$ & $53.30 \pm 1.24^{\mathrm{a}}$ & $26.32 \pm 0.91^{\mathrm{b}}$ & $7.81 \pm 2.78^{\mathrm{b}}$ \\
P. japonicum & $6.71 \pm 2.65^{\mathrm{b}}$ & $21.71 \pm 2.16^{\mathrm{b}}$ & $57.42 \pm 2.05^{\mathrm{a}}$ & $12.97 \pm 1.41^{\mathrm{a}}$ \\
G. littoralis & $17.64 \pm 1.22^{\mathrm{a}}$ & $11.43 \pm 1.57$ & $31.66 \pm 1.31^{\mathrm{b}}$ & $2.42 \pm 0.81$ \\
\hline
\end{tabular}

aMeans \pm standard deviation with the same letters within a column are not significantly different at $\mathrm{p}=0.05$ according to Duncan's multiple range test. ${ }^{b} \mathrm{dw}$ : dried weight

and antifungal effects, and antiinflammatory activity owing to NF-kB and MAPK activity. GL has polyine compounds, which are not phenolic, but have been reported to have antibacterial and antifungal activities $^{[28-32]}$. Other active constituents of GL include lignin and neolignan (polyphenolic substance) and biphenyl ferulate (flavonoid) ${ }^{[14,15]}$. The antimicrobial effects of the three plants could be of use against infectious disease. In the present study, the disc diffusion method indicated that ethyl acetate fraction is the most effective fraction against both Gram-positive and Gram-negative bacteria. Overall, Gram-negative bacteria were more sensitive to the three tested plants than Gram-positive bacteria, since the fractions of the three plants exhibited lower MIC values against Gram-negative bacteria. However, for Gram-positive bacteria, SD and PJ showed better effect than GL. Due to the differences in the activity and chemical properties, these plants should be used for specific purposes when employed as food additives and/or for medicinal purposes. DPPH free radical scavenging activity measures the degree of inhibition of DPPH free radicals. Regarding the antioxidant activity, SD in ether fraction and PJ in ethyl acetate fraction exhibited the highest antioxidant activity. The relation between antioxidant and total phenolic content for the three plant examined was shown (Table 2 and 3). All the three plants have antioxidant activity and their active components might be related to phenolic compounds, which have antioxidative and antimicrobial activity ${ }^{[13]}$. Lipopolysacchride (LPS) is a component of cell wall of Gram-negative bacteria and uses commonly for inflammation-associated researches. Anomalin, isolated from SD and a pyranocoumarin derivative, has antiinflammatory effect against LPS-induced macrophage activation. Also there is a report of antiinflammatory effect by GL on LPS-treated RAW 264.7 cells. Interestingly, there are no reports on the LPS or inflammation related research from $\mathrm{SD}^{[29,32]}$.

The results of the present study suggest that there are differences in the antimicrobial activity, antioxidant activity, and total polyphenol content among the three species of plants in the Umbelliferae family, which should be considered prior to their use for specific biotechnological, nutraceutical or pharmaceutical applications. It should be noted that this is a preliminary study and further investigations are needed to determine the mechanism of action of the investigated plants.

\section{Conflicts of interest:}

The authors declare that there are no conflicts of interest.

\section{Financial support and sponsorship:}

This study was supported by the National Research Foundation of Korea Grant funded by the Korean Government (NRF-2007-361-AM0015) and Suncheon Research Center for Natural Medicines.

\section{REFERENCES}

1. Tai J, Cheung S. Anti-proliferative and antioxidant activities of Saposhnikovia divaricata. Oncol Rep 2007;18:227-34.

2. Bonanomi G, Vinale F, Scala F. The role of natural products in plant-microbe interations. In: Osbourn A, Lanzotti V, editors. Plant-derived Natural Products. New York: Springer; 2009. p. 301-20.

3. Gao SH, Zhao GX, Yang XD, Xu LL. Preparation and antimicrobial effect of aromatic, natural and bacteriostatic foot wash with skin care. Zhongguo Zhong Yao Za Zhi 2013;38:2023-26.

4. Valente J, Zuzarte M, Goncalves MJ, Lopes MC, Cavaleiro $\mathrm{C}$, Salgueiro L, et al. Antifungal, antioxidant and antiinflammatory activities of Oenanthe crocata L. essential oil. Food Chem Toxicol 2013;62:349-54.

5. Mihailovic-Stanojevic N, Belscak-Cvitanovic A, GrujicMilanovic J, Ivanov $\mathrm{M}$, Jovovic $\mathrm{D}$, Bugarski $\mathrm{D}$, et al. Antioxidant and antihypertensive activity of extract from Thymus serpyllum L. in experimental hypertension. Plant Foods Hum Nutr 2013;68:235-40.

6. Rua J, Fernandez-Alvarez L, Gutierrez-Larrainzar M, del Valle P, de Arriag D, Garcia-Armesto MR. Screening of phenolic antioxidants for their inhibitory activity against foodborne Staphylococcus aureus strains. Foodborne Pathog Dis 2010;7:695-705.

7. Labuschagne, CF, Brenkman AB. Current methods in quantifying ROS and oxidative damage in Caenorhabditis elegans and other model organism of aging. Ageing Res Rev 2013;12:918-30. 
8. Chen XX, Wu XB, Chai WM, Feng HL, Shi Y, Zhou HT, et al. Optimization of extraction of phenolics from leaves of Ficus virens. J Zhejiang Univ Sci B 2013;14:903-15.

9. Zhao B, Yang XB, Yang XW, Liu JX. Biotransformation of prim-O-glucosylcimifugin by human intestinal flora and its inhibition on NO production and DPPH free radical. J Asian Nat Prod Res 2012;14:886-96.

10. Ruzic I, Skerget M, Knez Z. Potential of phenolic antioxidants. Acta Chim Slov 2010;57:263-71.

11. Gupta S, Banerjee R. Radical scavenging potential of phenolics from Bryophyllum pinnatum (LAM.) OKEN. Prep Biochem Biotechnol 2011;41:305-19.

12. Belkhir M, Rebai O, Dhaouadi K, Congiu F, Tuberoso CI, Amri M, et al. Comparative analysis of Tunisian wild Crataegus azarolus (Yellow Azarole) and Crataegus monogyna (Red Azarole) Leaf, Fruit and traditionally derived syrup: Phenolic profiles and antioxidant and antimicrobial activities of the aqueous-acetone extracts. J Agric Food Chem 2013;61:9594-601.

13. Mandal S, Patra A, Samanta A, Roy S, Mandal A, Mahapatra TD, et al. Analysis of phytochemical profile of Terminalia arjuna bark extract with antioxidative and antimicrobial properties. Asian Pac J Trop Biomed 2013;3:960-66.

14. Li J, Yuan Z. Biphenyl ferulate from Glehnia littoralis. Zhong Yao Cai 2005;28:553-55.

15. $\mathrm{Xu} \mathrm{Y,} \mathrm{Gu} \mathrm{X,} \mathrm{Yuan} \mathrm{Z.} \mathrm{Lignan} \mathrm{and} \mathrm{neolignan} \mathrm{glycosides} \mathrm{from}$ the roots of Glehnia littoralis. Planta Med 2010;76:1706-9.

16. Padda MS, Picha DH. Methodology optimization for quantification of total phenolics and individual phenolic acids in sweet potato (Ipomoea batatas L.) roots. J Food Sci 2007;72:412-16.

17. Kumar VP, Chauhan NS, Padh H, Rajani M. Search for antibacterial and antifungal agents from selected Indian medicinal plants. J Ethnopharmacol 2006;107:182-88.

18. Mahasneh AM, El-Oqlah AA. Antimicrobial activity of extracts of herbal plants used in the traditional medicine of Jordan. J Ethnopharmacol 1999;64:271-76.

19. Blois MS. Antioxidant determination by the use of a stable free radical. Nature 1958;26:1199-202.

20. Elekofehinti OO, Kamdem JP, Bolingon AA, Athayde ML, Lopes SR, Waczuk, EP, et al. African eggplant (Solanum anguivi Lam.) fruit with bioactive polyphenolic compounds exerts in vitro antioxidant properties and inhibits $\mathrm{Ca}(2+)$ induced mitochondrial swelling. Asian Pac J Trop 2013;3:757-66.

21. Silva LM, Figueiredo EA, Ricardo NM, Vieira IG, Figueiredo RW, Brasil IM, et al. Quantification of bioactive compounds in pulps and by-products of tropical fruits from Brazil. Food Chem 2014;143:398-404.

22. Kuo YC, Lin YL, Huang CP, Shu JW, Tsai WJ. A tumor cell growth inhibitor from Saposhnikovae divaricata. Cancer Invest 2002;20:955-64.

23. Kong X, Liu C, Zhang C, Zhao J, Wang J, Wan H, et al. The suppressive effects of Saposhnikovia divaricata (Fang feng) chromone extract on rheumatoid arthritis via inhibition of nuclear factor-kappa B and mitogen activated protein kinases activation on collagen-induced arthritis model. J Ethnopharmacol 2013;148:842-50.

24. Nukitrangsan N, Okabe T, Toda T, Inafuku M, Iwasaki H, Oku H. Effect of Peucedanum japonicum Thunb extract on high-fat diet-induced obesity and gene expression in mice. J Oleo Sci 2012;61:89-101.

25. Nukitrangsan $\mathrm{N}$, Okabe $\mathrm{T}$, Toda $\mathrm{T}$, Inafuku M, Iwasaki $\mathrm{H}$, Yanagita T, et al. Effect of Peucedanum japonicum Thunb on the expression of obesity-related genes in mice on a high-fat diet. J Oleo Sci 2011;60:527-36.

26. Hsiao G, Ko FN, Jong TT, Teng CM. Antiplatelet action of 3',4'-diisovalerylkhellactone diester purified from Peucedanum japonicum Thunb. Biol Pharm Bull 1998;21:688-92.

27. Huong DT, Choi HC, Rho TC, Lee HS, Lee MK, Kim YH. Inhibitory activity of monoamine oxidase by coumarins from Peucedanum japonicum. Arch Pharm Res 1999;22:324-6.

28. $\mathrm{Ng} \mathrm{TB}$, Liu F, Wang HX. The antioxidant effects of aqueous and organic extracts of Panax quinquefolium, Panax notoginseng, Codonopsis pilosula, Pseudostellaria heterophylla and Glehnia littoralis. J Ethnopharmacol 2004;93:285-88.

29. Huang GJ, Deng JS, Liao JC, Hou WC, Wang SY, Sung PJ, et al. Inducible nitric-oxide synthase and cyclooxygenase-2 participate in anti-inflammatory activity of imperatorin from Glehnia littoralis. J Agric Food Chem 2012;60:1673-81.

30. Matsuura H, Saxena G, Farmer SW, Hancock RE, Towers GH. Antibacterial and antifungal polyine compounds from Glehnia littoralis ssp. leiocarpa. Planta Med 1996;62:256-59.

31. Yoon T, Cheon MS, Lee AY, Lee DY, Moon BC, Chun JM, et al. Anti-inflammatory activity of methylene chloride fraction from Glehnia littoralis extract via suppression of NF-kappa B and mitogen-activated protein kinase activity. J Pharmacol Sci 2010;112:46-55.

32. Khan S, Shin EM, Choi RJ, Jung YH, Kim J, Tosun A, et al. Suppression of LPS-induced inflammatory and NF-kappaB responses by anomalin in RAW 264.7 macrophages. J Cell Biochem 2011;112:2179-88. 